Jurnal Keperawatan Silampari

Volume 2, Nomor 1, Desember 2018

e-ISSN : 2581-1975

p-ISSN : 2597-7482

DOI: https://doi.org/10.31539/jks.v2i1.316

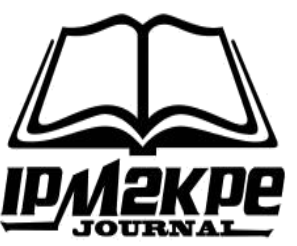

\title{
SCREENING POLA MAKAN PADA PASIEN DIABETES MELLITUS DENGAN FOOD FREQUENCY QUESTIONER
}

\author{
Nur Isnaini ${ }^{1}$, Isna Hikmawati ${ }^{2}$ \\ Program Studi Ilmu Keperawatan, Universitas Muhammadiyah Purwokerto ${ }^{1,2}$ \\ nurisnaini@ump.ac.id ${ }^{1}$
}

\begin{abstract}
ABSTRAK
Tujuan penelitian ini adalah untuk mengetahui screening pola makan pada pasien diabetes mellitus dengan food frequency questioner. Metode penelitian ini adalah penelitian deskriptif dengan melihat jenis makanan bahan pokok, sayur, buah dan makanan lain serta minuman menggunakan kuesioner food frequence. Rentang konsumsi berada pada rentang harian, mingguan, bulanan atau tahunan. Hasil penelitian, makanan yang paling sering dikonsumsi oleh pasien DM di Puskesmas 1 Cilongok yaitu sebanyak 24 orang $(60 \%)$ dan diikuti oleh konsumsi tempe yaitu sebanyak 22 orang $(55 \%)$ dengan frekuensi makan $>1 \mathrm{x}$ /harinya. Sayur sayuran yang sering dikonsumsi adalah kangkung sebanyak 34 orang (85\%) dan buah buahan yang sering dikonsumsi adalah mangga sebanyak 35 orang $(87.5 \%)$ dan pisang sebanyak 21 orang $(22.5 \%)$. Simpulan, Screening terhadap pasien DM tidak hanya dengan jenis makanan tetapi perlu dilakukan juga pengukuran jumlah dan jam makan sehingga dapat melihat jenis jumlah dan jam karena faktor makanan menjadi salah satu penyebab dari kejadian DM.
\end{abstract}

Kata Kunci : Diabetus Melitus, Food Frequence Questioner

\begin{abstract}
The purpose of this study was to determine dietary screening in patients with diabetes mellitus with a food frequency questioner. This research method is a descriptive study by looking at the type of food staples, vegetables, fruits and other foods and beverages using the food frequency questionnaire. The range of consumption is in the range of daily, weekly, monthly or yearly. The results of the study, the most frequently consumed foods by DM patients in Puskesmas 1 Cilongok are as many as 24 people (60\%) and followed by tempe consumption as many as 22 people (55\%) with a frequency of eating > 1x / day. Vegetables that are often consumed are kale as many as 34 people $(85 \%)$ and fruits that are often consumed are as many as 35 mango (87.5\%) and bananas as many as 21 people (22.5\%). Conclusion, Screening of DM patients is not only by type of food but it is also necessary to measure the amount and hours of meals so that they can see the type of amount and time because food is one of the causes of $D M$.
\end{abstract}

Keywords: Diabetus Melitus, Food Frequency Questioner 


\section{PENDAHULUAN}

Data Kemenkes RI (2013) dari hasil Riskesdas tahun 2013 angka kejadian Diabetes Mellitus mengalami peningkatan di Indonesia dari tahun 2007 sebanyak 1,1\% menjadi 2,1\% ditahun 2013. Analisis kejadian Diabetes Mellitus dilihat dari jenis kelamin di Indonesia tahun 2013 menunjukkan peningkatan Diabetes Mellitus terjadi pada perempuan lebih banyak sebesar $(1,7 \%)$ lebih banyak dibandingkan pada laki-laki $(1,4 \%)$. Berbeda dengan kategori wilayah kejadian Diabetes Mellitus di Indonesia tahun 2013 kejadian yang mengalami peningkatan lebih banyak terjadi di daerah perkotaan sebesar $(2 \%)$ sedangkan didaerah pedesaan sebanyak (1\%).

Data hasil dari Dinas Kesehatan Provinsi Jawa Tengah pada tahun 2014 Diabetes Mellitus berada pada urutan ke 2 dari 12 penyakit yang tidak menular (PTM) di Jawa Tengah yaitu sebanyak 95.342 (14,96\%) jiwa dari jumlah 620.293 jiwa (Dinkes Jateng, 2014) Prevalensi dari seluruh puskesmas di Kabupaten Banyumas tahun 2015, terdapat penderita diabetes melitus sebanyak 2106 penduduk yang terdiri dari DM tipe 1 sebanyak 563 dan DM tipe 2 sebanyak 1543, dan di tahun 2016 terdapat penderita diabetes mellitus sebanyak 1939 penduduk yang terdiri dari DM tipe 1 sebanyak 341 dan DM tipe 2 sebanyak 1598. Secara keseluruhan jumlah pasien DM sedikit menurun di tahun 2016 dibanding tahun 2015, namun jumlah penderita DM tipe 2 terus meningkat ditahun 2016 dibanding tahun 2015 (Dinkes Kabupaten Banyumas, 20152016).

Diabetes Mellitus (DM) yaitu suatu kelainan pada seseorang yang ditandai naiknya kadar glukosa dalam darah (Hiperglikemia) yang diakibatkan karena kekurangan Insulin, tanda dan gejala pasien DM seperti poliuria, polidipsia, dan polifagia (Padila, 2012). Masalah serius yang ada pada pasien DM adalah sebagian besar responden DM tidak mengikuti diet yang dianjurkan dengan mengurangi kalori. Penelitian lain menjelaskan bahwa faktor kepatuhan terhadap pengobatan lebih meningkat dibandingkan dengan faktor pengaturan diet, gaya hidup dan dan olahraga (Delamater, 2006). Menurut Almatsier (2006) menjelaskan bahwa seorang pasien dengan DM dengan patuh menjalani terapi nutrisi melalui diet secara rutin dan pengukuran level gula darah terkendali, bisa mengurangi kejadian komplikasi jangka pendek maupun jangka panjang serta komplikasi makro dan micro vaskuler. Kondisi pasien yang tidak patuh menjalankan terapi nutrisi melalui diet menyebabkan level gula darah tidak terkendali. Penyakit Diabetes Mellitus juga sangat dipengaruhi oleh pola makan dan kebiasaan. Sebuah teori menyebutkan bahwa pola makan adalah merupakan cara seseorang atau sekelompok dalam memilih makanan dan mengkonsumsinya dan akan bereaksi terhadap pengaruh psikologis, fisiologis, budaya dan sosial. Pola makan yang berlebih dapat mengakibatkan seseorang menjadi obesitas. Menurut Liao et al, (2011); National Diabetes Education Program, (2011); Pongsatha et al, (2012) kesalahan dalam pola makan dapat menyebabkan terjadinya obesitas dan kelebihan berat badan yang masalah tersebut berhubungan dengan peningkatan resiko kejadian diabetes melitus.

Kejadian obesitas diakibatkan salah satunya karena perubahan pola makan orang Indonesia seperti konsumsi makanan cepat saji atau fast food adalah jenis makanan yang mengandung tinggi energi dan lemak serta sangat diminati oleh masyarakat pada umumnya karena praktis, mudah dikemas dan disajikan. Selain kebiasaan tersebut dengan menjamurnya beberapa restoran fast food yang semakin banyak baik dikota besar maupun kota kecil di Indonesia sangat mempengaruhi pola makan tidak hanya remaja tetapi juga orang tua dan masyarakat secara umum karena selain praktis juga 
rasa dari makanan tersebut yang lezat. Sebuah restoran akan menyajikan beberapa makanan berupa jenis makanan fast food, western fast food dan juga dapat berupa traditional fast food. Western fast food merupakan makanan yang berasal dari eropa dengan dilah menjadi makanan yang terjangkau untuk masyarakat, cepat dalam penyajian, dengan penyajian yang menarik. Makanan western memiliki kandungan total energi tinggi berupa gula, lemak, natrium tetapi kandungan serat serta vitamin yang rendah. Jenis produk western fast food diantaranya kentang goreng atau french fries potato, hamburger, ayam goring tepung atau fried chicken, pizza, sandwich dan soft drink. Traditional fast food juga makanan yang memiliki kandungan gizi yang tidak seimbang. Contoh produk traditional fast food misalnya mie ayam, bakso, nasi goreng, soto, dan sate ayam (Riskesdas, 2013).

Terdapat beberapa metode untuk menilai konsumsi makanan terhadap individual maupun kelompok dengan menggunakan metode konsumsi harian kualitatif dan kuantitatif. Menurut Siagian (2010) terdapat enam metode yang sering digunakan untuk menilai konsumsi makanan pada seseorang yaitu dengan : (a) metode ingatan 24 jam (24-hours recall method), (b) metode pengulangan ingatan 24 jam (repeated 24-hours recall method), (c) metode pencatatan makanan (food record method), (d) metode penimbangan pangan (weighed food method), (e) metode riwayat makanan (dietary history), dan (f) metode frekuensi konsumsi pangan (food frequency method). Selain metode tersebut, masih ada metode yang lain yang sering digunakan juga adalah metode semi kuantitatif FFQ dan vitamin A semi questionaire method (VASQ). Salah satu kelebihan menggunakan kuesioner FFQ adalah sangat mudah murah dan sangat aplikatif diberikan pada semua golongan umur baik anak-anak maupun dewasa bahkan lansia.

Pengukuran pola makan dengan instrument Food Frequency Questioner (FFQ) paling sering digunakan untuk penilaian diet. Food frequency questioner adalah metode untuk memperoleh data tentang frekuensi konsumsi sejumlah bahan makanan atau makanan jadi selama periode tertentu seperti hari, minggu, bulan atau tahun. Dengan food frequency dapat diperoleh gambaran pola konsumsi bahan makanan secara kualitatif, tapi karena periode pengamatan lebih lama dan dapat membedakan individu berdasarkan rangking tingkat konsumsi zat gizi, maka cara ini paling sering digunakan dalam penelitian epidemiologi gizi (Supariasa, 2002). Sebagian FFQ justru memasukkan pertanyaan tentang bagaimana makanan biasanya diolah, penggunaan makanan suplemen, serta makanan bermerek lain (Arisman, 2004).

Data studi pendahuluan yang dilakukan oleh peneliti pada 9 maret 2016 dari puskesmas 1 cilongok kasus dm pada tahun 2016 terdiri dari DM tipe 2 sebanyak 109 kasus, dm tipe 1 sebanyak 2 kasus dan pada program pengelolaan penyakit kronis (prolanis) di puskesmas 1 cilongok terdapat 40 orang penderita dm tipe 2 yang mengikuti program prolanis. Berdasarkan latar belakang diatas dan banyaknya jumlah penderita DM di wilayah puskesmas 1 cilongok maka penelitian "Screening pola makan pada pasien DM di wilayah puskesmas 1 Cilongok dengan food frequency questioner " sangat perlu dilakukan.

\section{METODE PENELITIAN}

Penelitian ini menggunakan rancangan cross sectional yang penelitian ini menggunakan dua variabel berupa variabel bebas atau resiko dan variabel terikat atau variabel akibat dan data variabel penelitian akan dikumpulkan dalam waktu yang bersamaan. Populasi penelitian ini menggunakan semua pasien DM Tipe 2 yang 
tergabung dalam prolanis di Puskesmas 1 Cilongok sebanyak 40 orang. Teknik pengumpulan data yang digunakan dalam penelitian ini merupakan data primer yang diperoleh dari individu berupa Jenis kelamin, usia, TB, BB dan FFQ. Analisa univariat dalam penelitan ini dilakukan untuk mendeskripsikan: umur, jenis kelamin, BB, TB, dan frekuensi makan dengan FFQ. Kuesioner FFQ berisi tentang pertanyaan frekuensi pola makan dengan pembagian $>1 \mathrm{x} / \mathrm{hr}, 1 \mathrm{x} /$ hari, 4-6x/hari, 1-3x/minggu,1-3x/bulan dan tidak pernah untuk jenis makanan pokok, makanan lauk pauk ikan daging, ayam dan olahannya, jenis sayur, jenis minuman dan suplemen. Penyajian data menggunakan freskuensi dan prosentase.

\section{HASIL PENELITIAN}

Penelitian ini dilakukan di Wilayah Puskesmas 1 Cilongok Kabupaten Banyumas selama kurang lebih tiga bulan dimulai pada awal bulan Mei-Juli 2017. Setelah menemukan responden sesuai criteria kriteria inklusi dan eklusi dan dihitung menggunakan rumus sampling didapatkan sebanyak 40 orang responden. Selama proses penelitian berlangsung lancer, responden kooperatif, komunikasi lancer tidak hanya responden tetapi juga keluarga. Secara umum tidak ada kendala yang berarti. Berikut hasil penelitian disajikan dalam bentuk frekuensi dan prosentase untuk karakteristik responden dari usia, jenis kelamin dan antropometri serta hasil dari pembagian kuesioner FFQ yang terdiri dari bahan makanan pokok, sayuran, lauk pauk, minuman dan makanan olahan dan minuman yang hasil tersebut ditampilkan dalam bentuk tabel.

\section{Karakteristik Responden}

Tabel. 1

Karakteristik Responden Berdasarkan Jenis Kelamin, Usia, BB dan TB

\begin{tabular}{lcc}
\hline \multicolumn{1}{r}{ Variabel } & Jumlah & Prosentase \\
\hline Usia & & \\
$45-55$ & 19 & 47.5 \\
$56-65$ & 16 & 40 \\
$66-75$ & 3 & 7.5 \\
$>76$ & 2 & 5 \\
Total & 40 & 100 \\
& & \\
Jenis Kelamin & & \\
Lak-laki & 9 & 22.5 \\
Perempuan & 31 & 77.5 \\
Total & 40 & 100 \\
& & \\
\hline
\end{tabular}

Tabel 1 menunjukan karakteristik responden berdasarkan usia terbanyak adalah pada rentang usia 45-55tahun yaitu 19 orang atau $47.5 \%$. Peringkat kedua berada pada rentang 56-65 yaitu sebanyak 16 responden atau 40\%. Usia yang tertua pada rentang lebih dari 76 tahun sebanyak 2 orang atau 5\%. Jenis kelamin responden terbanyak adalah perempuan yaitu 31 orang atau $77.5 \%$ disusul dengan laki laki sebanyak 9 atau $22 \%$. 


\section{Antropometri Responden}

Tabel. 2

Antropometri TB dan BB

\begin{tabular}{lcccc}
\hline Variabel & $\mathrm{N}$ & Minimum & Maximum & Mean \\
\hline TB & 40 & 143 & 165 & 154.12 \\
BB & 40 & 39 & 70 & 53.83 \\
\hline
\end{tabular}

Tabel2 menunjukan TB responden rata rata $154.12 \mathrm{~cm}$ dengan TB minimum yaitu $143 \mathrm{~cm}$ dan maksimum adalah $165 \mathrm{~cm}$. BB rata rata $53.83 \mathrm{~cm}$ dengan nilai minimum $39 \mathrm{~kg}$ dan maksimum adalah $70 \mathrm{~kg}$.

\section{Frekuensi Makan Menggunakan Food Frequence Questionare}

Tabel 3

Screening Pola Makan Menggunakan Kuesioner FFQ untuk Bahan Makanan Pokok pada Pasien DM

\begin{tabular}{|c|c|c|c|c|c|c|c|c|c|c|c|c|c|}
\hline \multirow[t]{2}{*}{$\begin{array}{c}\text { Bahan } \\
\text { Makanan }\end{array}$} & \multicolumn{2}{|c|}{$>1 \mathrm{x} / \mathrm{hr}$} & \multicolumn{2}{|c|}{$1 \mathrm{x} / \mathrm{hr}$} & \multicolumn{2}{|c|}{$4-6 x / h r$} & \multicolumn{2}{|c|}{$1-3 x / m g g$} & \multicolumn{2}{|c|}{$1-3 x / b \ln$} & \multicolumn{2}{|c|}{$\begin{array}{c}\text { Tdk } \\
\text { pernah }\end{array}$} & \multirow[t]{2}{*}{$\begin{array}{c}\text { Total } \\
\%\end{array}$} \\
\hline & $\mathrm{n}$ & $\%$ & $\mathrm{n}$ & $\%$ & $\mathrm{~N}$ & $\%$ & $\mathrm{n}$ & $\%$ & $\mathrm{~N}$ & $\%$ & $\mathrm{n}$ & $\%$ & \\
\hline $\begin{array}{l}\text { Makanan } \\
\text { pokok }\end{array}$ & & & & & & & & & & & & & 100 \\
\hline Beras/Nasi & 34 & 85 & 2 & 5 & 3 & 7.5 & 1 & 2.5 & & & & & 100 \\
\hline Mie & 3 & 7.5 & & & & & 28 & 70 & 9 & 22.5 & & & 100 \\
\hline Kentang & & & & & & & 17 & 42.5 & 23 & 57.5 & & & 100 \\
\hline Singkong/ubi & & & & & & & 23 & 57.5 & & & 17 & 42.5 & 100 \\
\hline Roti putih & & & & & & & & & 35 & 87.5 & 5 & 12.5 & 100 \\
\hline Cereal & & & & & & & & & 4 & 10 & 36 & 90 & 100 \\
\hline Havermut & & & & & & & & & & & 40 & 100 & 100 \\
\hline Jagung & 2 & 5 & & & 2 & 5 & 6 & 15 & 30 & 75 & & & 100 \\
\hline
\end{tabular}

Tabel 3 menunjukan bahwa dari 40 responden penelitian pada pasien DM di Puskesmas 1 Cilongok terbanyak pada frekuensi lebih dari satu kali perhari $(>1 \mathrm{x} / \mathrm{hr})$ sebanyak 34 orang atau $85 \%$ menggunakan makanan pokok beras/nasi, tiga orang mengkonsumsi mie dan dua orang mengkonsumsi jagung. Dilihat dari frekuensi satu kali perhari $(1 \mathrm{x} / \mathrm{hr})$ untuk konsumsi beras atau nasi sebanyak dua orang atau $5 \%$. Frekuensi dilihat dari konsumsi 4-6x/hari didapatkan konsumsi beras sebanyak 3 orang atau $7.5 \%$. Frekuensi $1-3 \mathrm{x} / \mathrm{mgg}$ didapatkan konsumsi beras sebanyak 1 orang atau $2.5 \%$, mie sebanyak 28 orang atau $70 \%$, kentang 17 orang atau $42.5 \%$, dan singkong sebanyak $23 \%$ atau $57.5 \%$.

Dilihat dari frekuensi 1-3x/bulan didapatkan konsumsi mie sebanyak 9 orang atau $22.5 \%$, kentang sebanyak 23 orang atau $57 \%$, roti sebanyak 35 orang atau $87.5 \%$, cereal sebanyak 4 orang atau $10 \%$ dan jagung sebanyak 30 orang atau $75 \%$. Dilihat dari tabel makanan yang tidak pernah dimakan didapatkan singkong sebanyak 17 orang atau $42.5 \%$, roti sebanyak 5 orang atau $12.5 \%$, cereal sebanyak 36 orang atau $90 \%$, havermut sebanyak 40orang atau 100\%. Makanan yang selalu dimakan berupa nasi, mie, jagung, roti, cereal, ubi dan jagung.Makanan yang tidak pernah dimakan oleh responden adalah havermout. 
Tabel. 4

Screening Pola Makan Menggunakan Kuesioner FFQ

untuk Bahan Makanan Protein Hewani dan Nabati pada Pasien DM

\begin{tabular}{|c|c|c|c|c|c|c|c|c|c|c|c|c|c|}
\hline \multirow[t]{2}{*}{ Bahan Makanan } & \multicolumn{2}{|c|}{$>1 \mathrm{x} / \mathrm{hr}$} & \multicolumn{2}{|c|}{$1 \mathrm{x} / \mathrm{hr}$} & \multicolumn{2}{|c|}{$4-6 x / h r$} & \multicolumn{2}{|c|}{$1-3 x / m g g$} & \multicolumn{2}{|c|}{$1-3 x / b \ln$} & \multicolumn{2}{|c|}{$\begin{array}{c}\text { Tdk } \\
\text { pernah }\end{array}$} & \multirow{2}{*}{ Total \% } \\
\hline & $\mathrm{n}$ & $\%$ & $\mathrm{n}$ & $\%$ & $\mathrm{~N}$ & $\%$ & $\mathrm{n}$ & $\%$ & $\mathrm{n}$ & $\%$ & $\mathrm{n}$ & $\%$ & \\
\hline \multicolumn{14}{|l|}{$\begin{array}{l}\text { Ikan dan hasil } \\
\text { olahannya }\end{array}$} \\
\hline Ikan segar & 2 & 5 & & & & & 20 & 50 & 10 & 25 & 8 & 20 & 100 \\
\hline Ikan asin & 15 & 37.5 & & & 4 & 10 & 13 & 32.5 & 1 & 2.5 & 8 & 20 & 100 \\
\hline $\begin{array}{l}\text { Udang } \\
\text { dan lainnya: }\end{array}$ & & & & & & & 2 & 5 & 15 & 37.5 & 23 & 57.5 & \\
\hline \multicolumn{14}{|l|}{$\begin{array}{l}\text { Daging,telur dan } \\
\text { hasil olahannya }\end{array}$} \\
\hline Daging sapi & & & & & & & & & 39 & 97.5 & 1 & 2.5 & 100 \\
\hline Daging kambing & & & & & & & 7 & 17.5 & 10 & 25 & 23 & 57.5 & 100 \\
\hline Daging ayam & & & & & & & 30 & 75 & 5 & 12.5 & 5 & 12.5 & 100 \\
\hline Telur ayam & 12 & 30 & 3 & 7.5 & 2 & 5 & 5 & 12.5 & 10 & 25 & 8 & 20 & 100 \\
\hline Nugget & & & & & & & & & 35 & 87.5 & 5 & 12.5 & 100 \\
\hline Sosis & & & & & & & & & 23 & 57.5 & 17 & 42.5 & \\
\hline \multicolumn{14}{|l|}{ Kacang } \\
\hline $\begin{array}{l}\text { kacangan dan } \\
\text { hasil olahannya }\end{array}$ & & & & & & & & & & & & & 100 \\
\hline Kacang hijau & 4 & 10 & 6 & 15 & 1 & 2.5 & 27 & 67.5 & 2 & 5 & & & 100 \\
\hline Kacang tanah & 3 & 7.5 & & & 1 & 2.5 & 2 & 5 & 32 & 80 & 2 & 5 & 100 \\
\hline Tahu & 24 & 60 & 16 & 40 & & & & & & & & & 100 \\
\hline Tempe & 22 & 55 & 15 & 37.5 & 1 & 2.5 & 2 & 5 & & & & & \\
\hline
\end{tabular}

Tabel 4 frekuensi makan >1x/hari diperoleh konsumsi ikan segar sebanyak 2 orang atau 5\%, ikan asin sebanyak 15 orang atau $37.5 \%$, telur ayam sebanyak 12 orang atau $30 \%$, kacang hijau sebanyak 4 orang atau 10\%, kacang tanah sebanyak 3 orang atau $7.5 \%$, tahu sebanyak 24 orang atau $60 \%$, tempe sebanyak 22 orang atau sebanyak $55 \%$. Frekuensi $1 \times$ /hari berupa telur sebanyak 3 orang atau $7.5 \%$, kacang hijau sebanyak 6 orang atau $15 \%$, tahu 16 orang atau $40 \%$, tempe 15 orang atau $37.5 \%$.

Frekuensi makanan yang tidak pernah dimakan berupa ikan segar sebanyak 8orang atau 20\%, ikan asin 8 orang atau 20\%, udang 23 orang atau 57\%. Daging sapi 1 orang atau $2.5 \%$, daging kambing sebanyak 23 orang atau $57.5 \%$, ayam 5 orang atau $12.5 \%$, telur ayam 8 orang atau $20 \%$, nugget 5 orang atau $12.5 \%$, sosis 17 orang atau 42.5\%. Tabel tersebut menunjukan bahwa tahu adalah makanan yang paling sering dikonsumsi oleh pasien DM di Puskesmas 1 Cilongok yaitu sebanyak 24 orang (60\%) dan diikuti oleh konsumsi tempe yaitu sebanyak 22 orang (55\%) dengan frekuensi makan $>1 x$ /harinya. Makanan yang sering dimakan dari jenis daging adalah berupa daging ayam, telor dan makanan yang jarang dimakan berupa kambing, nugget dan sosis. 
Tabel. 5

Screening Pola Makan Menggunakan Kuesioner FFQ untuk Bahan Makanan Sayur Sayuran dan Buah Buahan pada Pasien DM

\begin{tabular}{|c|c|c|c|c|c|c|c|c|c|c|c|c|c|}
\hline \multirow[t]{2}{*}{$\begin{array}{c}\text { Bahan } \\
\text { Makanan }\end{array}$} & \multicolumn{2}{|c|}{$>1 \mathrm{x} / \mathrm{hr}$} & \multicolumn{2}{|c|}{$1 \mathrm{x} / \mathrm{hr}$} & \multicolumn{2}{|c|}{$4-6 x / h r$} & \multicolumn{2}{|c|}{$\begin{array}{c}1- \\
3 \mathrm{x} / \mathrm{mgg}\end{array}$} & \multicolumn{2}{|c|}{$1-3 x / b \ln$} & \multicolumn{2}{|c|}{$\begin{array}{c}\text { Tdk } \\
\text { pernah }\end{array}$} & \multirow[t]{2}{*}{$\begin{array}{c}\text { Total } \\
\%\end{array}$} \\
\hline & $\mathrm{n}$ & $\%$ & $\mathrm{n}$ & $\%$ & $\bar{N}$ & $\%$ & $\mathrm{n}$ & $\%$ & $\mathrm{n}$ & $\%$ & $\frac{\mathrm{r}}{\mathrm{n}}$ & $\%$ & \\
\hline Sayur sayuran & & & & & & & & & & & & & 100 \\
\hline Bayam & 2 & 5 & & & & & & & 21 & 52.5 & 17 & 42.5 & 100 \\
\hline Kangkung & & & & & & & & & 34 & 85 & 6 & 15 & 100 \\
\hline $\begin{array}{l}\text { Daun singkong } \\
\text { Sawi hijau }\end{array}$ & 7 & 17.5 & & & & & & & 3 & 7.5 & 30 & 75 & 100 \\
\hline Kol & 7 & 17.5 & 3 & 7.5 & 2 & 5 & 8 & 20 & 12 & 30 & 8 & 20 & 100 \\
\hline Kembang kol & & & & & & & & & 35 & 87.5 & 5 & 12.5 & 100 \\
\hline Brokoli & & & & & & & & & 2 & 5 & 38 & 95 & 100 \\
\hline Timun & & & & & & & 6 & 15 & 34 & 85 & & 0 & 100 \\
\hline Kacang & 2 & & & & & & & & & & & & \\
\hline panjang & & 5 & 3 & 7.5 & 6 & 15 & 4 & 10 & 25 & 62.5 & & 0 & 100 \\
\hline Buncis & 5 & 12.5 & 1 & 2.5 & & & 16 & 40 & 15 & 37.5 & 3 & 7.5 & 100 \\
\hline Buah buahan & & & & & & & & & & & & & 100 \\
\hline Jeruk & 10 & 25 & 2 & 5 & 4 & 10 & 4 & 10 & 20 & 50 & & & 100 \\
\hline Pisang & 9 & 22.5 & 21 & 52.5 & & & & & 10 & 25 & & & 100 \\
\hline Pepaya & 5 & 12.5 & 15 & 37.5 & & & 6 & 15 & 4 & 10 & 20 & 50 & 100 \\
\hline Mangga & & & & & & & & & 35 & 87.5 & 5 & 12.5 & 100 \\
\hline Apel & 1 & 2.5 & 4 & 10 & & & & & 27 & 67.5 & 8 & 20 & 100 \\
\hline
\end{tabular}

Tabel 5 menunjukan frekuensi makan $>1 \mathrm{x} / \mathrm{hr}$ dari golongan sayur sayuran adalah bayam sebanyak 2 orang atau 5\%, daun singkong 7 orang atau $17.5 \%$, kol 7 orang atau $17.5 \%$, kacang panjang 2 orang atau 5\%, buncis 5 orang atau 12.5\%. Dari jenis makanan buah berupa jeruk 10 orang, pisang 9 orang atau $22.5 \%$, papaya 5 orang atau $12.5 \%$, apel 1 orang atau $2.5 \%$. Frekuensi $1 \mathrm{x} / \mathrm{hr}$ didapatkan kol 3 orang atau $7.5 \%$, kacang panjang 3 orang atau $7.5 \%$, buncis 1 orang atau $2.5 \%$. Makanan yang tidak pernah dikonsumsi untuk buah papaya sebanyak 20 orang atau $50 \%$, mangga 5 orang atau $12.5 \%$, dan apel 8 orang atau $20 \%$. Dari jenis sayuran makanan yang tidak pernah dimakan adalah bayam 17 orang atau 42.5\%, kangkung 6 orang atau $15 \%$, daun singkong 30 atau $75 \%$, kol 8 orang atau 20\%, kembang kol 5 orang atau $12.5 \%$, brokoli 38 orang atau $95 \%$ dan buncis 3 orang atau $7.5 \%$.

Frekuensi makan $1 \mathrm{x} /$ hari berupa kol 3 orang atau $7.5 \%$, kacang panjang 3 orang atau $7.5 \%$, buncis 1 orang atau 2.5\%. Kategori buah jeruk 2 orang, pisang 21 orang, papaya 15 orang, apel 4 orang. Sayuran yang paling sering dikonsumsi adalah kangkung sebanyak 34 orang $(85 \%)$ dan buah buahan yang sering dikonsumsi adalah mangga sebanyak 35 orang $(87.5 \%)$ dan pisang sebanyak 21 orang (22.5\%). Frekuensi makan 1$3 \mathrm{x} /$ minggu kategori buah berupa jeruk sebanyak 4 orang atau $10 \%$, dan papaya sebanyak 6 orang atau 15\%. Jenis makanan dengan kategori jarang dikonsumsi atau 1 $3 x /$ bulan untuk buah buahan adalah jeruk 20 orang atau 50\%, pisang 10 orang atau $25 \%$, papaya 4 orang atau $10 \%$, mangga 35 orang atau $87.5 \%$, apel 27 orang atau $67.5 \%$. 
Tabel. 6

Screening Pola Makan Menggunakan Kuesioner FFQ untuk Bahan Makanan Susu, Makanan Jajanan, Soft Drink dan Suplemen pada Pasien DM

\begin{tabular}{|c|c|c|c|c|c|c|c|c|c|c|c|c|c|}
\hline \multirow[t]{2}{*}{ Bahan Makanan } & \multicolumn{2}{|c|}{$>1 \mathrm{x} / \mathrm{hr}$} & \multicolumn{2}{|c|}{$1 \mathrm{x} / \mathrm{hr}$} & \multicolumn{2}{|c|}{$4-6 x / h r$} & \multicolumn{2}{|c|}{$1-3 x / m g g$} & \multicolumn{2}{|c|}{$1-3 x / b \ln$} & \multicolumn{2}{|c|}{ Tdk pernah } & \multirow{2}{*}{$\begin{array}{l}\text { Total } \\
\%\end{array}$} \\
\hline & $\mathrm{n}$ & $\%$ & $\mathrm{n}$ & $\%$ & $\mathrm{~N}$ & $\%$ & $\mathrm{n}$ & $\%$ & $\mathrm{n}$ & $\%$ & $\mathrm{~N}$ & $\%$ & \\
\hline $\begin{array}{l}\text { Susu dan hasil } \\
\text { olahannya }\end{array}$ & & & & & & & & & & & & & 100 \\
\hline Yoghurt & & & & & & & & & & & 40 & 100 & 100 \\
\hline Keju & & & & & & & & & & & 40 & 100 & 100 \\
\hline Ice cream & & & & & & & & & 5 & 12.5 & 35 & 87.5 & \\
\hline Makanan jajanan & & & & & & & & & & & & & \\
\hline Hamburger & & & & & & & & & & & 40 & 100 & 100 \\
\hline Hotdog & & & & & & & & & & & 40 & 100 & 100 \\
\hline Pizza & & & & & & & & & & & 40 & 100 & 100 \\
\hline Fried chicken & & & & & & & & & 21 & 52.5 & 19 & 47.5 & 100 \\
\hline Spagetty & & & & & & & & & & 0 & 40 & 100 & 100 \\
\hline French fries & & & & & & & & & 2 & 5 & 38 & 95 & 100 \\
\hline Donat & & & & & & & & & 5 & 12.5 & 35 & 87.5 & 100 \\
\hline Bakso & 3 & 7.5 & 1 & 2.5 & 1 & 2.5 & 1 & 2.5 & 25 & 62.5 & 9 & 22.5 & 100 \\
\hline Siomay & 15 & 37.5 & 5 & 12.5 & & & & & 10 & 25 & 10 & 25 & 100 \\
\hline Batagor & 6 & 15 & & & 10 & 25 & & & 14 & 35 & 8 & 20 & 100 \\
\hline Pempek & & & & & & & & & 6 & 15 & 34 & 85 & 100 \\
\hline Roti & & & & & & & & & 8 & 20 & 32 & 80 & 100 \\
\hline Cake & & & & & & & & & & & 40 & 100 & 100 \\
\hline Puding/agar2 & & & & & & & & & & & 40 & 100 & 100 \\
\hline Coklat & & & & & & & & & & & 40 & 100 & \\
\hline
\end{tabular}

Tabel 6 frekuensi makan untuk bahan makanan susu dan hasil olahannya tidak pernah dikonsumsi berupa yoghurt dan keju sebanyak 40 orang atau $100 \%$, untuk ice cream jarang dikonsumsi 1-3x/bulan sebanyak 5 orang atau $12.5 \%$ sedangkan yang tidak pernah konsumsi ice cream sebanyak 35 orang atau $87.5 \%$. Untuk bahan makanan jajanan yang dikonsumsi $>1 \mathrm{x} /$ hari berupa bakso 3 orang atau $7.5 \%$, siomay 15 orang atau $37.5 \%$, batagor 6 orang atau 15\%. Untuk kategori jarang yaitu 1-3x/bulan jenis makanan fried chicken 21 orang atau $52.5 \%$, kentang goreng 2 orang atau 5\%, donat 5 orang atau $12.5 \%$, bakso 25 orang atau $62.5 \%$, batagor 14 orang atau $35 \%$.

Tabel. 7

Screening Pola Makan Menggunakan Kuesioner FFQ untuk Makanan Berupa Soft Drink dan Suplemen Serat

\begin{tabular}{|c|c|c|c|c|c|c|c|c|c|c|c|c|c|}
\hline \multirow[t]{2}{*}{ Bahan Makanan } & \multicolumn{2}{|c|}{$>1 \mathrm{x} / \mathrm{hr}$} & \multicolumn{2}{|c|}{$1 \mathrm{x} / \mathrm{hr}$} & \multicolumn{2}{|c|}{$4-6 x / h r$} & \multicolumn{2}{|c|}{$1-3 x / m g g$} & \multicolumn{2}{|c|}{$1-3 x / b \ln$} & \multicolumn{2}{|c|}{ Tdk pernah } & \multirow[t]{2}{*}{ Total $\%$} \\
\hline & $\mathrm{n}$ & $\%$ & $\mathrm{n}$ & $\%$ & $\mathrm{n}$ & $\%$ & $\mathrm{n}$ & $\%$ & $\mathrm{n}$ & $\%$ & $\mathrm{n}$ & $\%$ & \\
\hline Soft drink & & & & & & & & & & & & & 100 \\
\hline Coca cola & & & & & & & & & & & 40 & 100 & 100 \\
\hline Fanta & & & & & & & & & 2 & 5 & 38 & 95 & 100 \\
\hline Sprite & & & & & & & & & 1 & 2.5 & 39 & 97.5 & 100 \\
\hline Pepsi & & & & & & & & & & & 40 & 100 & 100 \\
\hline Pop ice & & & & & & & & & & & 40 & 100 & 100 \\
\hline Suplemen serat & & & & & & & & & & & & & \\
\hline Biolisin & & & & & & & 1 & 2.5 & & & 39 & 97.5 & 100 \\
\hline
\end{tabular}

Tabel 7 menunjukan bahwa konsumsi coca cola tidak pernah dikonsumsi, fanta tidak pernah dikonsumsi oleh 38 orang atau 95\%, sprite tidak pernah dikonsumsi oleh 39 orang atau $97.5 \%$. Untuk konsumsi frekuensi 1-3x/bulan jenis minuman fanta sebanyak 2 orang atau $5 \%$, sprite 1 orang atau $2.5 \%$. Untuk jenis minuman suplemen 
serat berupa biolisin dikonsumsi 1-3x/minggu sebanyak 1 orang atau $2.5 \%$ dan tidak pernah 39 orang atau $97.5 \%$.

\section{PEMBAHASAN}

\section{Karakteristik Responden}

Tabel 1 menunjukan karakteristik responden berdasarkan usia terbanyak adalah pada rentang usia 45-55tahun yaitu 19 orang atau 47.5\%. Jenis kelamin responden terbanyak adalah perempuan yaitu 31 orang atau 77.5\%. Tabel 2 menunjukan TB responden rata rata $154.12 \mathrm{~cm}$ dengan TB minimum yaitu $143 \mathrm{~cm}$ dan maksimum adalah $165 \mathrm{~cm}$. BB rata rata $53.83 \mathrm{~cm}$ dengan nilai minimum $39 \mathrm{~kg}$ dan maksimum adalah $70 \mathrm{~kg}$.

Penelitian yang dilakukan pada pasien DM Tipe 2 di Puskesmas 1 Cilongok jumlah responden terbanyak adalah perempuan. Usia responden lebih dari setengahnya adalah berada pada rentang 45-55 tahun. Pendapat dari Iswanto (2004) menjelaskan bahwa terdapat hubungan yang bermakna antara usia dengan kejadian diabetes mellitus. Penelitian oleh Sunjaya (2009) juga menemukan bahwa kelompok usia dengan perhitungan jumlah terbanyak terkena penyakit diabetes mellitus adalah kelompok umur 45-52 (47,5\%).

Bertambahnya kasus kejadian Diabetes beriringan dengan bertambahnya usia, terutama pada usia yang lebih dari 40 tahun karena pada usia tersebut mulai terjadi tubuh mengalami peningkatan intoleransi glukosa. Adanya proses penuaan menyebabkan berkurangnya kemampuan sel $\beta$ pancreas dalam memproduksi insulin (Sunjaya, 2009). Individu dengan usia lebih tua terdapat kondisi penurunan aktivitas mitokondria didalam sel otot sebesar $35 \%$ dan juga berhubungan dengan peningkatan kadar lemak di otot sebesar 30\% serta memicu terjadinya resistensi insulin (Sherwood, L. 2012).

Penelitian yang dilakukan oleh Iswanto (2004) menghasilkan bahwa ada hubungan yang bermakna antara usiadengan kejadian diabetes mellitus. Selanjutnya penelitian yang dilakukan oleh Sunjaya (2009) menemukan bahwa kelompok usia dengan terbanyak menderita diabetes mellitus adalah kelompok umur 45-52 (47,5\%). Peningkatan kejadian diabetes seiring dengan bertambahnya umur, terutama pada usia lebih dari 40 tahun karena pada usia tersebut mulai terjadi peningkatan intolenransi glukosa. Adanya proses penuaan menyebabkan berkurangnya kemampuan sel $\beta$ pancreas dalam memproduksi insulin (Sunjaya, 2009). Kondisi individu yang berusia lebih tua menyebabkan penurunan aktivitas mitokondria di sel-sel otot sebesar 35\%yang berhubungan dengan peningkatan kadar lemak di otot sebesar $30 \%$ serta memicu terjadinya resistensi insulin.

\section{Antropometri Pasien DM Tipe 2}

Tabel 2 menunjukan TB responden rata rata $154.12 \mathrm{~cm}$ dengan TB minimum yaitu $143 \mathrm{~cm}$ dan maksimum adalah $165 \mathrm{~cm}$. BB rata rata $53.83 \mathrm{~cm}$ dengan nilai minimum $39 \mathrm{~kg}$ dan maksimum adalah $70 \mathrm{~kg}$. Kondisi peningkatan berat badan merupakan faktor predisposisi untuk timbulnya peningkatan kadar gula darah dikarenakan sel-sel beta pulau Langerhans menjadi kurang peka terhadap rangsangan atau akibat naiknya kadar gula dan kegemukan juga akan menekan jumlah reseptor insulin pada sel - sel seluruh tubuh (Guyton, 2007).

Tingginya jumlah masalah kelebihan berat badan dan obesitas juga diakui menjadi masalah global oleh World Health Organization (WHO) dan juga menjadi masalah 
utama di negara-negara berkembang. Peningkatan penghasilan dan kematuran tingkat ekonomi, perpindahan dan perubahan lifestyle secara jelas menunjukkan bahwa negaranegara berkembang sedang menghadapi masalah yang sama yaitu berat badan lebih dan obesitas. Indonesia sebagai salah satu negara berkembang sedang dalam proses transisiatau perubahan gizi yang cepat dengan tingkat obesitas yang terus meningkat. Indonesia saat ini sedang menghadapi dua masalah yang pertama adalah nutrisi kurang dan yang kedua adalah nutrisi lebih, dengan kenaikan tingkat berat badan lebih dan obesitas pada anak dan dewasa, yang merupakan bentuk malnutrisi yang mengancam generasi mendatang dengan meningkatnya risiko untuk penyakit kronis (Dickey et al, 2010).

Kelebihan jaringan lemak pada tubuh akan dapat menimbulkan hiperlipidemia, resistensi insulin, dan diabetes mellitus tipe 2. Kelebihan jaringan lemak atau yang disebut dengan obesitas adalah keadaan yang makin sering dijumpai masyarakat modern dan dikaitkan dengan resistensi insulin serta kejadian diabetes (Ganong, 2008). Program olahraga yang baik, benar, teratur dan terukur membantu menstabikan kadar gula darah, mengurangi kebutuhan insulin dan obat-obatan serta memelihara berat badan (Perkeni, 2011).

Kondisi ini dipengaruhi faktor herediter, aktivitas fisik, asupan diet, keluaran energi, metabolisme dan hormonal. Metabolisme lemak tergantung pada kebutuhan energi dan diatur oleh makanan serta sinyal - sinyal saraf dan hormonal. Oksidasi parsial asam lemak menghasilkan keton yang merupakan sumber bahan bakar alternatif untuk otak dan berbagai organ. Jaringan lemak berfungsi untuk tempat penyimpanan cadangan energi dan juga sebagai jaringan yang dinamis dengan berbagai fungsi.

Indeks masa tubuh pada level obesitas terjadi karena ketidakseimbangan antara masukan energi dengan keluarnya energi yang kondisi tersebut mengakibatkan kelebihan energi yang akan disimpan dalam bentuk jaringan lemak dan akan disimpan dalam bentuk glycogen oleh hati. Kelebihan energi tersebut dapat disebabkan oleh asupan energi yang tinggi atau keluaran energi yang rendah. Penyebab terjadinya ketidakseimbangan antara asupan dan pembakaran kalori ini masih belum jelas, namun terjadinya obesitas diakibatkan karena faktor genetik, lingkungan, gaya hidup dan psikis. Retensi insulin dan gangguan toleransi glukosa pada penderita obesitas akan berpengaruh pada kadar gula darah.

Angka gula darah yang berada pada level tinggi akan beresiko untuk masuk dalam kondisi pradiabetes. Kondisi pradiabetes merupakan kondisi dimana kadar gula darah berada pada level lebih tinggi dari, tetapi belum cukup untuk mendiagnosa pasien dengan positif diabetes. Kondisi pradiabetes jika tidak ditangani dengan baik, bisa menjadi positif diabetes. Perubahan status dari level pradiabetes menjadi DM tipe II bisa berlangsung kurang lebih membutuhkan waktu 10 tahun (Suyoto, 2011). Angka kematian akibat DM erat kaitannya dengan kondisi obesitas, obesitas yang erat hubungannya dengan sindrom metabolik adalah obesitas sentral. Metabolik Sindroma dalah kelompok masalah dengan kelainan metabolik diluar masalah obesitas berupa gangguan toleransi glukosa, retensi insulin, abnormalitas trigliserida, ketidakstabilan tekanan darah, diabetes militus tipe II, penyakit jantung koroner, stroke, penyakit kandung empedu serta kanker endometrium, payudara, prostat, dan kolon.

Menurut International Diabetes Federation (2006) obesitas menimbulkan masalah metabolisme dan juga masalah diskriminasi sosial. Obesitas menjadi faktor penyebab munculnya peningkatan kadar gula darah karena sel-sel beta pulau langerhans menjadi tidak peka terhadap rangsangan atau akibat naiknya kadar gula dan kegemukan 
juga akan menjadi penyebab tertekannya jumlah reseptor insulin pada sel seluruh tubuh (Guyton, 2007). Hasil uji koefisien korelasi bahwa IMT obesitas mempengaruhi kadar gula darah meskipun $\mathrm{p}$ value tidak menunjukan hubungan yang signifikan. Kondisi ini dipengaruhi faktor herediter, aktivitas fisik, asupan diet, keluaran energi, metabolisme dan hormonal. Metabolisme lemak tergantung pada kebutuhan energi dan diatur oleh makanan serta sinyal - sinyal saraf dan hormonal.

\section{Frekuensi Pola Makan dengan Food Frequence Questioner}

Food Frequency Questioner adalah alat penilaian diet yang banyak digunakan dalam studi epidemiologi yang menyelidiki hubungan antara asupan makanan dan penyakit atau faktor risiko sejak awal tahun 90an. Tiga komponen utama kuesioner ini adalah daftar makanan, frekuensi konsumsi dan berapa kali dikonsumsi. Daftar makanan harus mencerminkan kebiasaan makanan dari populasi penelitian pada saat data dikumpulkan. Frekuensi konsumsi mungkin diminta oleh pertanyaan terbuka atau dengan menampilkan kategori frekuensi (Michels, 2009).

Kuesioner Frekuensi Makanan kuantitatif tidak meminta responden untuk memperkirakan ukuran porsi yang dikonsumsi baik dalam ukuran rumah tangga atau gram tetapi hanya melihat apa saja yang dikonsumsi dengan jenis jenis makanan berupa makanan pokok, protein, sayur dan buah serta makanan dan minuman tambahan. FFQ sangat efektif biaya sehingga mendorong penggunaannya secara luas dalam studi kohort epidemiologi berskala besar dan juga dalam rancangan penelitian lainnya. Pengkodean dan pengolahan data yang dikumpulkan juga lebih murah dan membutuhkan keahlian gizi kurang dibandingkan metode asupan asupan makanan lainnya. Namun keterbatasan utama adalah kesalahan dan bias sistematis dalam perkiraan. Upaya penting sedang dikembangkan untuk meningkatkan kualitas informasi (Kristiansen, 2013).

Tabel 3 menunjukan bahwa dari 40 responden penelitian pada pasien DM di Puskesmas 1 Cilongok terbanyak menggunakan makanan pokok beras/nasi sebanyak 34 orang $(85 \%)$ dengan frekuensi makan $>1 \mathrm{x}$ /hari dan sebanyak 2 orang mengkonsumsi beras sebanyak 1x/hari. Bahan makanan singkong dikonsumsi oleh 23 (57\%) selama 1$3 x /$ minggunya. Sebanding dengan penelitian yang dilakukan oleh Isnaini (2016) terhadap pasien DM di wilayah Puskesmas Purwojati didapatkan data bahwa pasien dengan level gula darah $>200 \mathrm{mg} / \mathrm{dl}$ berpengaruh dengan indeks masa tubuh dan IMT dengan obesitas berhubungan dengan tingginya konsumsi karbohidrat.

Faktor penyebab terjadinya peningkatan level gula darah adalah konsumsi makanan tinggi karbohidrat sederhana, tinggi lemak, dan makanan olahan dan kurangnya aktifitas fisik dan olahraga. Terdapat korelasi antara tingginya konsumsi karbohidrat dan lemak terhadap peningkatan kadar gula darah (Erliensty, 2009). Jika jumlah karbohidrat lebih banyak dari kemampuan tubuh untuk melakukan pembakaran sebagai sumber energi, maka karbohidrat akan dikonversikan menjadi lemak (American Diabetes Acociation, 2015).

Jika konsumsi karbohidrat sederhana terlalu banyak akan menyebabkan cepatnya hormon insulin memproduksi untuk menjadi pasangan dari gula agar proses gula darah bisa segera masuk ke sel otot atau pun sel hati. Kondisi berbeda jika jika tempat penyimpanan gula sudah penuh maka akan disimpan didalam otot atau hati, gula juga akan di simpan di dalam sel lemak yang didalam sel lemak gula akan di ubah menjadi lemak (Turoan, 2012). Makronutrien berupa lemak adalah sumber energi terbesar yang dapat menyebabkan kelebihan berat badan dan obesitas. Kondisi orang yang mengalami obesitas maka sel-sel lemak tersebut akan menghasilkan beberapa zat yang zat tersebut 
digolongkan menjadi adipositokin dan zat tersebut menjadikan kondisi resistensi terhadap pengeluaran insulin. Kondisi resistensi insulin akan menyebabkan gula darah sulit masuk ke dalam sel dan kondisi ini akan menyebabkan hiperglikemi atau peningkatan gula darah (Kariadi, 2009).

Makanan makronutrien berupa karbohidrat yang didalam tubuh akan dicerna dan menghasilkan gula dan energi, dan ada juga karbohidrat yang dirubah dalam bentuk glycogen dalam hati sebagai cadangan serta disimpan dalam bentuk lemak. Fungsi utama karbohidrat untuk metabolisme adalah menyediakan energi untuk sel, termasuk sel-sel otak yang kerjanya tergantung pada suplai karbohidrat berupa glukosa. Kondisi kurangnya glukosa darah dapat mengakibatkan hipoglikemia, sedangkan kondisi kelebihan glukosa dalam darah menimbulkan kondisi yang disebut hiperglikemia yang kondisi tersebut jika berlangsung terus dapat meningkatkan resiko terjadinya penyakit diabetes (Mahan et al, 2012).

Tingginya jumlah penderita penyakit diabetes mellitus di Indonesia diakibatkan kebiasaan pola makan orang Indonesia yang terlalu banyak mengkonsumsi karbohidrat dan ketidakseimbangan konsumsi dengan kebutuhan energi yang jika kondisi tersebut berlangsung terus menerus dapat menimbulkan terjadinya diabetes mellitus. Penderita Diabetes mellitus mengalami kondisi resistensi insulin yang menyebabkan peningkatan tekanan darah, kadar glukosa darah, hiperinsulinemia dan ketidaknormalan fungsi lemak yang akan muncul tanda berupa adanya peningkatan LDL, kadar kolesterol darah, dan penurunan HDL ataupun peningkatan kadartrigliserida dalam darah yang menjadi faktor utama terjadinya penyakit jantung (Waspadji, S. 2009).

Penulis mengambil kesimpulan bahwa tingginya angka kejadian DM di Puskesmas 1 Cilongok salah satunya adalah dipengaruhi oleh faktor pola makan yang dibuktikan dengan hasil penelitian terhadap 40 responden dengan positif DM pola makan karbohidrat yaitu nasi dikonsumsi $>1 \mathrm{x} /$ hari, selain itu juga hasil wawancara terhadap responden diketahui bahwa sebelum terkena DM terbiasa dengan konsumsi minuman manis dan makanan manis. Penelitian ini hanya melihat jenis makanan yang dikonsumsi dengan frekuensi makan dalam satu sampai 3 bulanan dan tidak melihat jumlah dari jenis makanan yang dikonsumsi sehingga hasil ini tidak dapat melihat bagaimana jumlah dan waktu konsumsi pasien. 


\section{SIMPULAN}

Karakteristik responden berdasarkan usia terbanyak adalah pada rentang usia 4555tahun, peringkat kedua berada pada rentang 56-65. Usia yang tertua pada rentang lebih dari 76 tahun. Jenis kelamin responden terbanyak adalah perempuan.

TB responden rata rata $154.12 \mathrm{~cm}$ dengan TB minimum yaitu $143 \mathrm{~cm}$ dan maksimum adalah $165 \mathrm{~cm}$. BB rata rata $53.83 \mathrm{~cm}$ dengan nilai minimum $39 \mathrm{~kg}$ dan maksimum adalah $70 \mathrm{~kg}$.

Jenis makanan pokok menunjukan bahwa dari 40 responden penelitian pada pasien DM di Puskesmas 1 Cilongok terbanyak pada frekuensi lebih dari satu kali perhari $(>1 \mathrm{x} / \mathrm{hr})$ menggunakan makanan pokok beras/nasi, tiga orang mengkonsumsi mie dan dua orang mengkonsumsi jagung. Makanan yang selalu dimakan berupa nasi, mie, jagung, roti, cereal, ubi dan jagung. Makanan yang tidak pernah dimakan oleh responden adalah havermout.

Makanan yang paling sering dikonsumsi oleh pasien DM di Puskesmas 1 Cilongok yaitu dan diikuti oleh konsumsi tempe dengan frekuensi makan $>1 \mathrm{x} /$ harinya.

Makanan jenis ikan yang sering dikonsumsi adalah ikan asin dengan frekuensi $>1 \mathrm{x} /$ hari.

Makanan jenis kacang dan olahannya paling sering adalah tahu dan diikuti oleh konsumsi tempe dengan frekuensi makan $>1 \mathrm{x}$ /harinya.

Sayur sayuran yang sering dikonsumsi adalah kangkung dan buah buahan yang sering dikonsumsi adalah mangga dan pisang.

Bahan makanan berupa jajanan yang sering dikonsumsi adalah siomay, batagor dan bakso yang dikonsumsi $>1 \mathrm{x} / \mathrm{hari}$. Untuk semua jenis minuman responden dengan kategori tidak pernah ada pada jenis coca cola, fanta dan sprite.

\section{SARAN}

Saran bagi Puskesmas 1 Cilongok dengan kejadian tingginya angka kejadian DM dan melihat hasil penelitian ini bahwa pasien DM terbanyak adalah mengkonsumsi karbohidrat berupa nasi yang dikonsumsi> 1x/hari. Edukasi yang dapat diberikan adalah dengan mengatur pola makan dan memilih jenis karbohidrat dengan rendah kalori serta jadwal makan atau lebih sering disebut dengan $3 \mathrm{~J}$ yaitu jenis jumlah dan jam makan. Selain itu juga perlu disosialisasikan pilar penanganan DM berupa edukasi, olahraga, minum obat teratur dan control rutin untuk mengetahui level gula darah. Saran untuk penderita DM sebaiknya memperhatikan jenis jumlah dan jam makan untuk dapat menstabilkan level gula darah dan agar terhindar dari komplikasi. Saran bagi peneliti selanjutnya data jumlah makanan dan waktu makan atau jam perlu ditambahkan untuk mengetahui selain jenis juga jumlah dan jam. Data lain yang perlu ditambah dan diteliti adalah adanya faktor keturunan, pola hidup, dukungan keluarga, kategori Indeks Masa Tubuh dan faktor faktor yang melatar belakangi pasien DM di Puskesmas 1 Cilongkok. 


\section{DAFTAR PUSTAKA}

ADA. (2015). Diagnosis and Classification of Diabetes Mellitus. Diabetes Care, 35(1). Care.diabetesjournals.org

Almatsier, S. (2006). Prinsip Dasar Ilmu Gizi. Jakarta: Gramedia

Arisman.(2004). Gizi dalam Daur Kehidupan. Jakarta: Buku Kedokteran EGC. 180-195

Departemen Kesehatan Indonesia. (2013). Khomsan A. Pangan dan Gizi untuk Kesehatan. Jakarta: PT. Rajagrafindo Persada; 2004;120-122

Delamater, A. M. (2006). Improving Patient Adherence. Diabetes Journal. Diakses 10 Januari (2017). Website: http://www.clinical.diabetesjournals.org/

Dinkes Jateng. (2014). Profil Kesehatan Provinsi Jawa Tengah 2014. Semarang: Pemerintah Provinsi Jawa Tengah

Dinas Kesehatan Kabupaten Banyumas. (2016). Profil Kesehatan Kabupaten Banyumas Tahun 2015. Pemerintah Kabupaten Banyumas

Dickey, V., Boedihardjo, S., Bardosono, T. (2010). USAID/Indonesian Nutrition Assessment for 2010 New Project Design

Eysteinsdottir, T., Thorsdottir, I., Gunnarsdottir, I., \& Steingrimsdottir, L. (2012). Assessing Validity of a Short Food Frequency Questionnaire on Present Dietary intake of elderly Icelanders. Nutrition Journal, 11(12). http://doi.org/10.1186/1475-2891-11-12

Guyton A.C. \& J.E. Hall. (2007). Buku Ajar Fisiologi Kedokteran. Edisi 9. Jakarta: EGC

Ganong, William F. (2008). Fisiologi Kedokteran. Edisi 22. Jakarta: Penerbit Buku Kedokteran EGC

Iswanto. (2004). Beberapa Faktor yang Berhubungan dengan Kadar Gula Darah Puasa Pasien Rawat Jalan Diabetes Melitus Tipe 2 Pukesmas Pasar Minggu. Skripsi . Jakarta. FKM UI

Isnaini N, Hikmawati I. (2016). Pengaruh Indeks Masa Tubuh (IMT) terhadap Kadar Gula Darah Sewaktu (GDS)

International Diabetes Federation. (2006). The IDF Consensus Worldwide Definition of the Metabolic Syndrome

Kristiansen, A. L., Laugsand Lillegaard, I. T., \& Frost Andersen, L. (2013). Effect of Changes in a Food Frequency Questionnaire: Comparing Data from Two National Dietary Survey Instruments Among 12-Month-Old Infants. BMC Public Health, 13, 680.http://doi.org/10.1186/1471-2458-13-680

Kariadi, S. H. (2009). Diabetes?Siapa Takut: Panduan Lengkap untuk Diabetesi, Keluarganya, dan Professional Medis. Bandung: PT.Mizan Pustaka

Kemenkes RI. (2013). Hasil Riskesdas Tahun 2013. Jakarta: Banlitbangkes

Liao YL, Lin SC, Hsu CH. (2011). Waist Circumference is a Better Predictor than Body Mass Index of Insulin Resistance in Type 2 Diabetes. Int J Diabetes \& Metab, 19, $35-40$

Michels, K. B., \& Willett, W. C. (2009). Self-Administered Semiquantitative Food Frequency Questionnaires: Patterns, Predictors, and Interpretation of Omitted Items. Epidemiology (Cambridge, Mass.), 20(2), 295-301. http://doi.org/10.1097/EDE.0b013e3181931515

Mahan LK, Stump SE, Raymond JL. (2012). Krause's Food and the Nutrition Care Process. (Ed. 13). Elsevier, 758-769 
National Diabetes Education Program. (2011). 4Steps to Control Your Diabetes for Life, NIH publication, 11-5492 Supariasa, dkk. 2002. "Penilaian Status Gizi". Jakarta: Penerbit Buku Kedokteran EGC

Ns Padila. (2012). Buku Ajar Keperawatan Medikal Bedah. Yogyakarta: Nuha Medika

Pongsatha S, Morakot N, Sangchun K, Chaovisitsaree S. (2012). Correlation Between Waist Circumference and Other Factors in Menopausal Women in THAILAND. $4(2), 60-65$

Riskesdas. (2013). Badan Penelitian dan Pengembangan Kesehatan. Riset Kesehatan Daerah

Sunjaya, I Nyoman.(2009). Pola Konsumsi Makanan Tradisional Bali sebagai Faktor Risiko Diabetes Melitus Tipe 2 di Tabanan. Jurnal Skala Husada, 6(1), 75-81

Sherwood, L. (2012). Fisiologi Manusia dari Sel ke Sistem, Ed 6. Jakarta: EGC

Siagian, A. (2010). Epidemiologi Gizi. Jakarta: Erlangga

Perkeni. (2011). Konsensus Pengelolaan Diabetes Melitus Tipe 2 di Indonesia2011. Semarang: PB Perkeni

Waspadji, S. (2009). Komplikasi Kronik Diabetes Mekanisme Terjadinya, Diagnosis dan Strategi Pengelolaan: Buku Ajar Ilmu Penyakit Dalam Jilid III Edisi V. Balai Penerbit Fakultas Kedokteran Universitas Indonesia 